Contents available at: Sri Lanka Journals Online

\title{
Assessing the Potential for an Improved Solid Waste Collection in Kalmunai, Sri Lanka: An Analysis of Willingness to Pay
}

\author{
A. Dilsath ${ }^{1}$, D.V.P. Prasada ${ }^{1,2^{*}}$ \\ ${ }_{1}^{1}$ Postgraduate Institute of Agriculture, University of Peradeniya, Peradeniya, 20400, Sri Lanka. \\ ${ }^{2}$ Department of Agricultural Economics and Business Management, Faculty of Agriculture, University of Peradeniya. \\ Peradeniya, 20400, Sri Lanka.
}

\section{ARTICLE INFO}

\section{Article history:}

Received: 13 August 2020

Revised version received: 04 October 2020

Accepted: 22 June 2021

Available online: 01 October 2021

\section{Keywords:}

household waste

Kalmunai

municipal waste collection

willingness to pay

\section{Citation:}

Dilsath, A. and Prasada, D.V.P. (2021) Assessing the potential for an improved solid waste collection in Kalmunai, Sri Lanka: An analysis of willingness to pay. Tropical Agricultural Research, 32(4): 434-444.

DOI: http://doi.org/10.4038/tar.v32i4.8512

Dilsath, A.

https://orcid.org/0000-0002-2881-3762

\section{ABSTRACT}

Rapid population growth and increase of economic activities combined with a lack of training in modern solid waste management practices complicate the efforts to improve the solid waste services. Poor waste management has led to indiscriminate dumping of solid waste into open spaces and drainages, blocking drains and causing flooding, environment pollution and public health issues. Collecting fees from the public can support finance for improving waste management service. This study intended to evaluate willingness to pay (WTP) of households for improved solid waste collection service in two selected zones of Kalmunai municipal council area. The survey covered 140 households using a stratified simple random sampling method from two selected zones. This study used a contingent valuation method to elicit households' WTP and multiple linear regression models to determine factors influencing WTP. The household willingness to pay was significantly affected by gender, education, average income, householder's concern about environment and cost of collecting $1 \mathrm{~kg}$ of waste. Gender and education were statistically significant at $p<0.05$, average income and cost of collecting $1 \mathrm{~kg}$ of waste were statistically significant at $p<0.1$ and householder's concern about environment was statistically significant at $p<0.01$. The results of this study show that the mean willingness to pay of households to organic/kitchen waste and plastic/paper waste was LKR $2.8 / \mathrm{kg}$ and LKR $2.63 / \mathrm{kg}$, respectively.

\footnotetext{
*Corresponding author: prasada@agri.pdn.ac.lk
} 


\section{INTRODUCTION}

Municipal solid waste management (SWM) is a worldwide problem and it is becoming more and more complicated (Singh et al., 2011). The accelerated growth of urban population with unplanned urbanization, increasing economic activities and lack of training in modern solid waste management practices in the developing countries complicate the efforts to improve solid waste services (Asian Institute of Technology, 2004). This has led to indiscriminate dumping of solid waste into open spaces and drainages, blocking drains and causing flooding, environment pollution and public health issues. A significant portion of the municipal budget is spent on SWM in Asian countries but economic growth and improvement of living standards have resulted in the substantial increase in the amount of solid waste being generated, making SWM even more challenging (Asian Productivity Organization, 2007).

As at present, management of municipal solid waste in Sri Lanka, collection to treatment, is not at a satisfactory level. Only a fraction of the total municipal solid waste generated in Sri Lanka is collected by the local authorities (Gunaruwan and Gunasekara, 2016). The waste generation in Sri Lanka has increased by two-fold (approximately) over a period of 10 years due to the economic growth. In Sri Lanka, solid waste generation is around $0.65-0.85 \mathrm{~kg} /$ day/person (UNEP, 2011) and household waste typically carries high content of organic matter, moderate content of plastics and paper and low content of metal and glass. Disposal of solid waste is a priority environmental issue in Sri Lanka.

Although solid waste has been identified to be one of the major causes for environmental degradation, the most common method of municipal solid waste disposal still remains to be open dumping, leading to many environmental and health problems (Gunawardana et al., 2009). In open dumping, the waste which is collected by local authorities is placed in open dump sites of low-lying, degraded land where all types of waste are disposed of with no separation, resulting in the release of landfill gases and leachate, and reducing flood retention capacity of suburban areas. Septic tank sludge is also often disposed of at the open dumps, with no environmental or health precautions (Environmental Foundation, 2007), posing a significant health risk to those living around the dumps. Dump sites are generally small (1-2 hectares), so workers managing the sites regularly burn waste in an effort to extend the life of the dump which also has negative consequences (Environmental Foundation, 2007).
The local area councils, municipal councils, and urban councils are responsible for waste collection and disposal in their territories. Most of the local authorities are incapable of handling the total amount of waste generated in its area due to financial and resource constraints. Also, most expenditure is directed to the collection and transportation of the waste, making investments in the disposal and treatment inadequate (Mahees, 2011). In the Kalmunai municipality, weaknesses such as inadequate financial resources, scarcity of land, lack of social responsibility, insufficient technical, improper choice of technology and lack of public awareness of solid waste management have made SWM far from satisfactory. Therefore, the key question here is how much households are willing to pay for efficient and cost-effective delivery of solid waste collection services. Thus, this study tries to evaluate WTP by households for an improved SWM service of waste collection. Specifically, the study examined the general features of the existing solid waste management and disposal practices of the households, identified the socio- economic variables, determine how much the households are willing to pay for an improved solid waste collection service and determine the factors influencing their preferences.

Overall, we observe that there is an extensive global literature on the willingness to pay for solid waste management. Some studies have shown that the willingness to pay for solid waste management is associated with income, education, quantity of waste generated, household size, and age. However, similar information is missing in many municipalities in the local context. In particular, the site that we are focusing falls in the DS division with the highest population density in Sri Lanka, but an efficient and effective waste collection system is missing. This is mainly due to the inability to cost and price the economic basis of such a system. Therefore, investigating a payment system for waste collection is addressed in this study for a selected sample of households using a contingent valuation approach.

\section{METHODOLOGY}

Various studies have shown that residents are willing to pay for a better waste disposal service. However, their willingness to pay for such services depends on many socio-demographic factors. Addai and Danso-Abeam (2014), in a study of willingness to pay for improved solid waste management in Ghana, maintain that age, household size and income associate positively with consumers' willingness to pay for an improved solid waste management system. 
Besides, they find that females have a positive WTP and males have a negative WTP. Ojok et al., (2012) also find that gender significantly influences households' willingness to pay for solid waste disposal services. Afroz et al. (2009) state that variables like household expenditure, quantity of waste generated and level of education have a significant influence on consumers' WTP. Aggrey and Douglason (2010) hypothesize that the higher the level of education, the more they would appreciate the consequences of mishandling solid waste, and the more they would be willing to pay in order to avoid the risk of being victims of an unclean environment. Afroz et al. (2009) also emphasize that education relates to a better understanding of the problem of solid waste and hence a higher WTP for waste disposal services. Ekere et al. (2010) emphasize that the location of the household is significant factor for households' willingness to pay for solid waste management. All these findings empirically show that there is a correlation between educational levels and consumers' WTP for improved solid waste disposal services. Satisfaction with waste collection services further influences WTP for improved waste management. People who are more satisfied with waste collection services are willing to pay more than dissatisfied people (Afroz et al., 2009).

The contingent valuation method has been applied in both developed and developing countries for valuation of a number of environmental and natural resources. However, despite the fact that solid waste management in most cities of the developing world is unsatisfactory and consumes a relatively high proportion of their municipal budgets, only few studies have applied contingent valuation to solid waste management in developing countries. Wel and Post (2007) indicate that simple and inexpensive household surveys can provide valuable inputs into planning processes. A contingent valuation method is done through presenting a hypothetical description or scenario to a study participant and asking the amount the participant is willing to value a good or service given the specified terms and conditions of the scenario. The latter is done by asking how much an individual is willing-to-pay or willing-to-accept on some changes on the provision. The response validity relates to the willingness-to-pay responses of the participant to his/her socio-demographic and economic characteristics. Confirmation of a priori expectations of the relationship between willingness-to-pay and other variables are often associated with contingent valuation studies. A contingent valuation exercise involves informing the respondent about the prevailing situation (prices, environmental conditions, etc), and then informs him/her about a change. The individual is asked to value a particular change in environmental conditions in a future hypothetical scenario. Contingent valuation has advantages over the other methods of environmental valuation such as the travel-cost and hedonic pricing techniques. The method is able to quantify some types of benefits, such as non-use or passive use benefits, which lie outside the scope of travel-cost and hedonic pricing studies. In addition, in contingent valuation, the respondents are free to answer the open-ended questions by indicating the maximum amount that they are willing to pay.

\section{Study area}

This study was carried out in 2019 at Kalmunai Municipal Council (KMC) area in Ampara district. KMC occupies part of the Ampara district of Eastern province of Sri Lanka. KMC has a width of $1.5 \mathrm{~km}$ East-West and $10 \mathrm{~km}$ North-South. The eastern boundary faces the Indian Ocean. It has 04 zones, 23 wards and $76 \mathrm{GN}$ divisions. It covers a total area of approximately $22.9 \mathrm{~km}^{2}$. It had a total population of 117,102 as of 2015 . KMC consists of four major regions, namely, Kalmunai city (Thalavatuvan Junction to Zahira College Road), Kalmunai North (Pandiruppu, Maruthamunai and Neelavanai), Kalmunai South (Sainthamaruthu) and Kalmunai West (Natpittimunai, Chenaikudiruppu).

The survey was conducted in selected zones of KMC. Kalmunai city consists of four zones namely zones A,B,C and D. Two zones were selected out of the four zones. Those were zone A (Sainthamarthu) and zone D (Periyaneelavanai, Maruthamunai and Pandiruppu). Total population of zones A and D is 65,081 . The stratified random sampling method was used to select the respondent households, where each zone was taken as a stratum. In order to take a sample that can be representative, 140 households were sampled from both zones, 70 households per each zone. Data was obtained in person through face-to face interviews.

\section{Enumeration and empirical analysis}

Primary and secondary data were used in the study. Primary data were taken from personal interviews with the 140 household heads using a questionnaire. Data collected included the socio and economic characteristics of the household head, details of the household solid waste generation, details of waste collection service, concerns about solid waste management, and their willingness to pay for an improved solid waste collection service. 


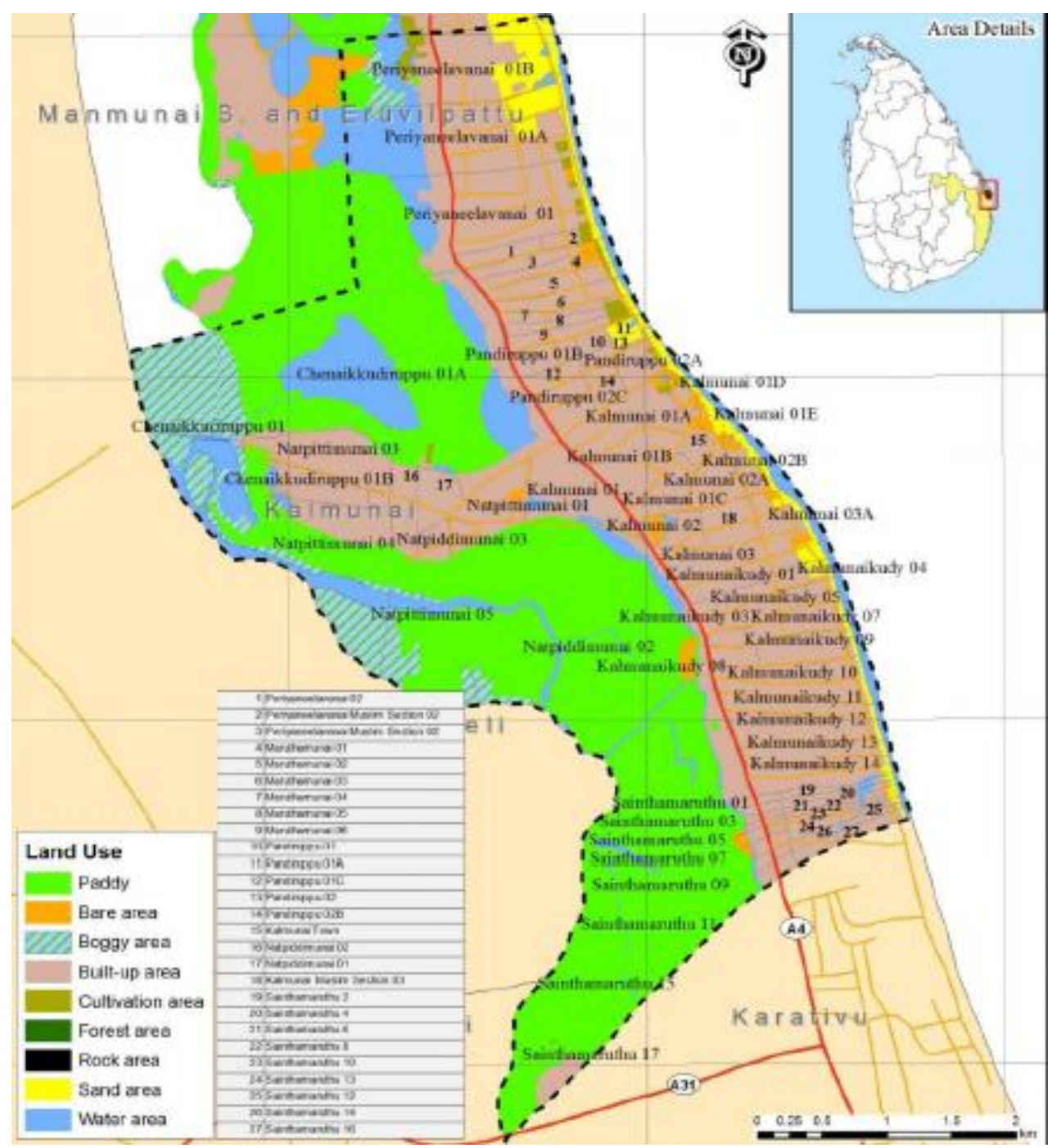

Figure 1. Study area map

Research questionnaire contained five sections: (A) Household information (B) Household solid waste management (C) waste collection service (D) concern about solid waste management (E) household willingness to pay. Descriptive statistics such as frequency distribution tables, mean and standard deviation were used to analyse the socioeconomic characteristics of the respondents. To identify the factors influencing WTP for improved waste collection service by KMC, a regression model involving socioeconomic characteristics of the household was used.

To elicit WTP, double-bounded dichotomous choices were used in this study. The doublebounded dichotomous choices and open-ended question method generated data to estimate the WTP for waste collection service in Kalmunai municipality. In dichotomous choice methods, the respondent only answers 'yes' or 'no' to a given question about the WTP amount. The first question would be followed by another question specifying a lower amount, if the answer to the first question were negative. To avoid the initial bid (or stated value) bias, we used three different starting bids (see Figure 2). If the respondent rejected all three declining bids, the willingness to pay was taken as zero. In the end, what we obtain is a WTP variable carrying four levels of value as willingness to pay per Kg of waste. Compared to other elicitation methods, this procedure was evaluated to have the most significant statistical efficiency (Ghosh and Mondal, 2011; Lang, 2010). This method was used to estimate the WTP to dispose $1 \mathrm{~kg}$ of kitchen/organic and paper/plastic waste. 


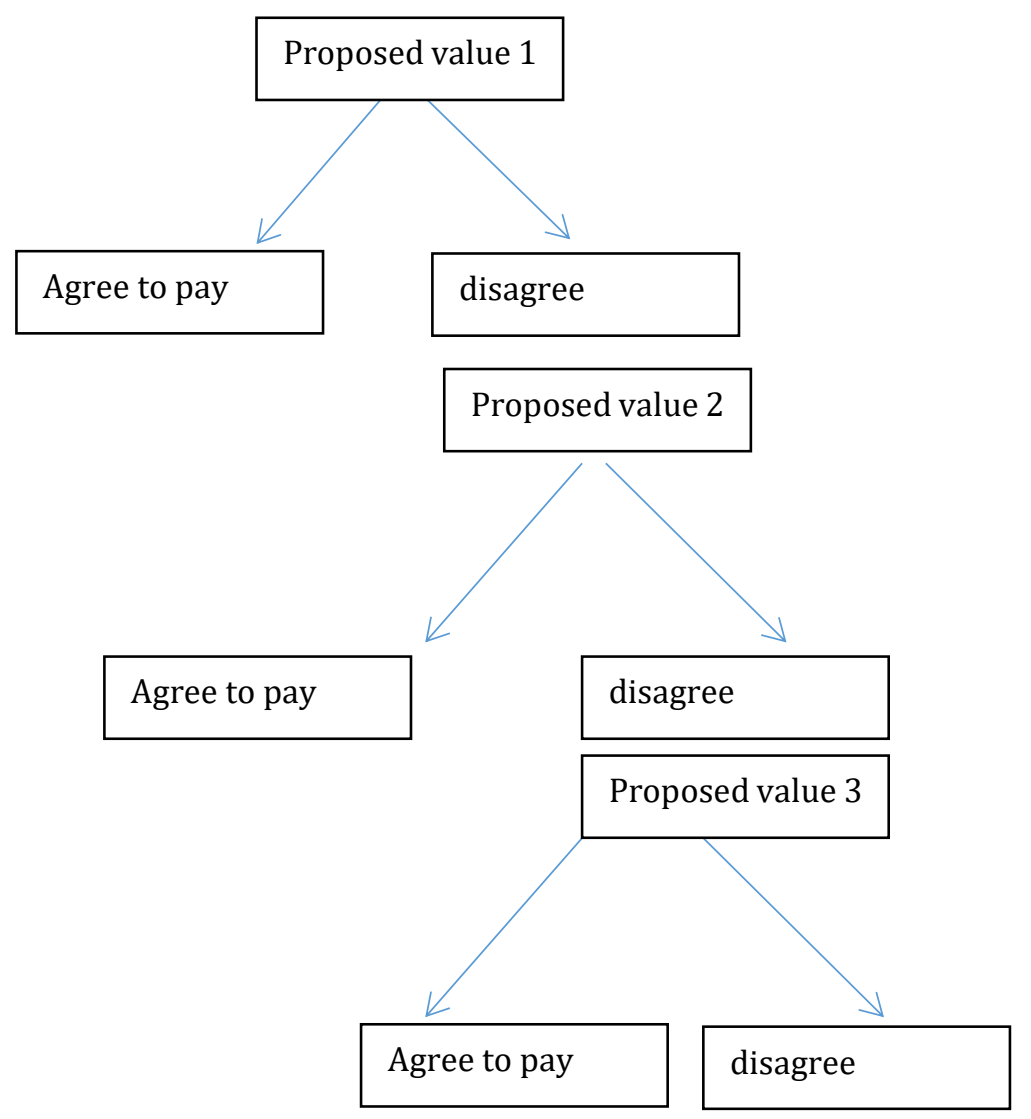

Figure 2. Elicitation procedure

In the regression model, the dependent variable was the WTP value elicited in the survey. The multiple linear regression models were used to identify the determinants of households' WTP for improved waste collection service, i.e. dispose $1 \mathrm{~kg}$ of kitchen/organic and dispose $1 \mathrm{~kg}$ of paper/plastic waste respectively. The regressors include age of the household head in years, gender of the household head, educational level measured by number of years spent in the school, marital status, household size (number), household total monthly income (LKR/month), degree of concern about environment, weight of household waste, views of service quality provided by KMC, and perceived cost of collecting $1 \mathrm{~kg}$ of waste.

\section{RESULTS AND DISCUSSION}

This study was conducted in Kalmunai municipality of Ampara where SWM service is restricted by the limited resources. Solid waste disposal is a common threat to environment in KMC since most of the solid waste ends up directly in open landfill or dumps. In KMC, there is approximately above 27 tons of waste generated every day and of that, only $50 \%$ are collected.

\section{Sample description}

The majority of the household heads in the surveyed area were male $(66.43 \%)$, and most of the study participants were married (90\%). Most of the household heads (42.15\%) were involved in government jobs. $34.28 \%$ of them involved in selfemployment activities, $14.28 \%$ of them involved in private jobs and rest of them were unemployed. The responses on income distribution showed that $60.71 \%$ had average monthly income between LKR 20,001 - 50,000, 22.86\% had average monthly income between LKR 10,001 - 20,000, 12.14\% had average monthly income between LKR 50,001100,000 . The rest of the respondents had average monthly income below LKR10,000. Results also indicated that all respondents live in their own house.

About $72.86 \%$ of the total household heads stated that household waste management was the major problem in the area (Figure 1). Other major problems identified included sewage pollution from pits and toilets (43.57\%), automobile exhaust (50.71\%), factories, tree-felling, pesticides and overfishing respectively. 


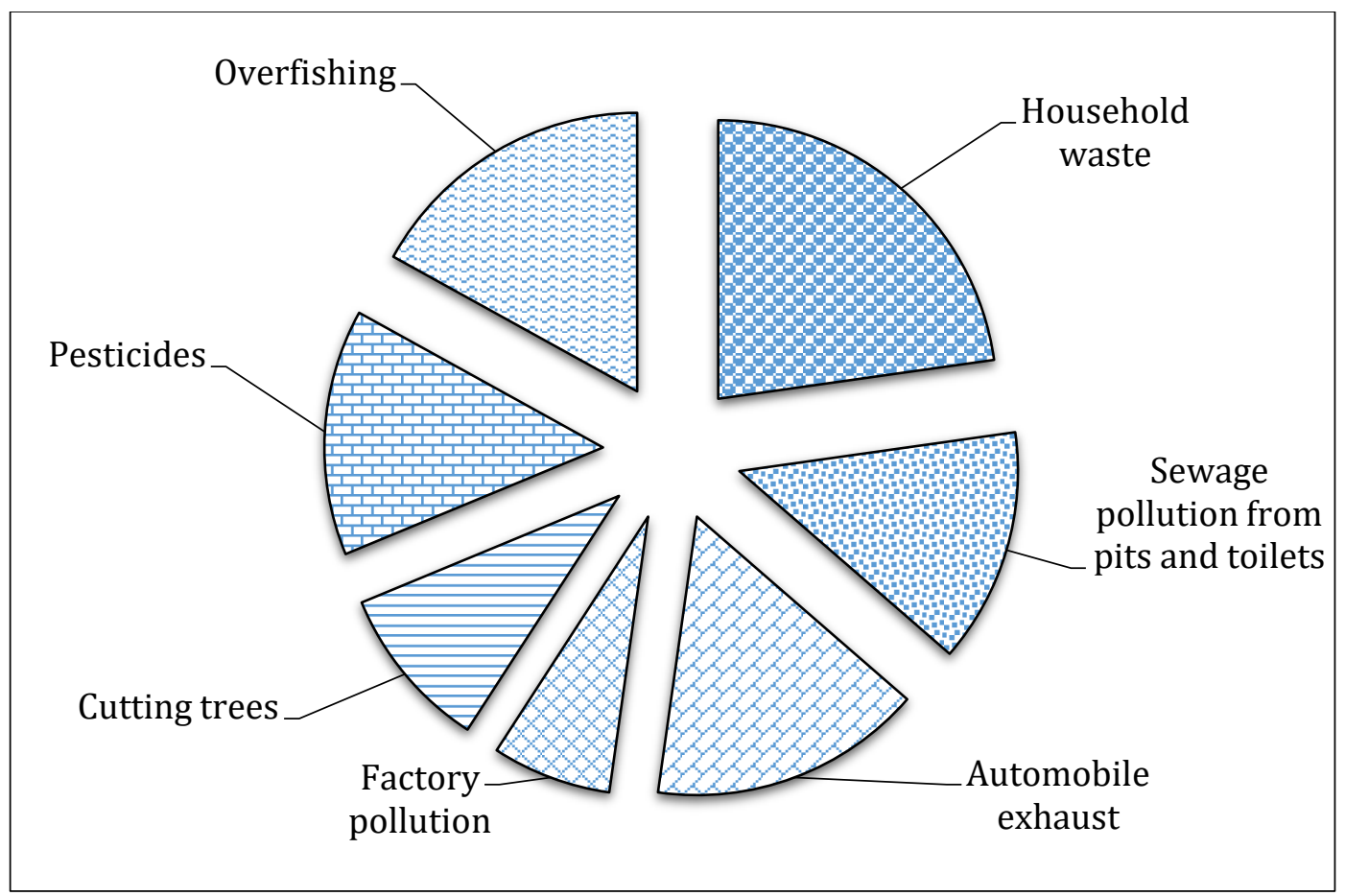

\section{Figure 3. Major environmental issues in Kalmunai municipality (stated)}

Majority (62.86\%) of the households used polythene bags to store the household wastes. Only $27.14 \%$ of the households used open container, $6.43 \%$ of the households used closed container and $3.57 \%$ of the households dumped waste in the yard. The average quantity of solid waste generated by a household was $2.52 \mathrm{~kg} /$ day meanwhile minimum and maximum quantity of solid waste generated by a household was $0.5 \mathrm{~kg}$ /day and $4.5 \mathrm{~kg} /$ day respectively.

Households' solid waste disposal methods were also examined by category/type of waste (Table 1 ). Food waste was disposed by households using several methods: urban council collection truck (70.71\%), feed for animals (19.29\%) and buried in their home $(5.71 \%)$. Plastics, paper, metals, glass and other wastes were mostly disposed by households through the existing urban council collection service. Meanwhile, only $3.57 \%$ of the household reused the paper. $83.57 \%$ of the households did not separate their household waste while $16.43 \%$ of the households separated their waste before to disposal. $53.57 \%$ of the household were not interested in separating their household waste even if they were instructed. Only $46.43 \%$ of households declared willingness to separate their waste.

$39.29 \%$ of the households stated that the municipal collection service is available once a week in their location. Another $37.14 \%$ of the households stated that the collection service is available twice a month and only $23.57 \%$ stated that service is available once a month. Most of the households (42.86\%) were satisfied with existing collection service of the municipal council. About $40.71 \%$ of the household participants were not satisfied with existing collection service as per the received responses.

Almost all the households stated that the frequency of the urban council collection service was not sufficient implying that the interval between the collections is too long (Table 2). $63.79 \%$ of the households mentioned that the collection workers were impolite and $36.21 \%$ of the households realized that the service of the urban council was not reliable. $52.14 \%$ of the households knew where the collected waste is taken for final disposal when it leaves their household and rest of the households (47.86\%) did not know. $65 \%$ of the households were concerned that the disposal of such collected waste was environmentally safe. Household views/concerns about solid waste management were also examined as shown in Table 3. Results show that $82.86 \%$ of the household heads believed that the burning of waste generates a health risk. About $83.57 \%$ of the household heads were concerned about diseases (e.g. Dengue, Malaria) that were related to improper storage and disposal of waste. 
Table 1. Methods of household disposal of different type of waste.

\begin{tabular}{llrr}
\hline Type of waste & Methods of disposal & Frequency & Percentage \\
\hline Food waste & Municipal council truck & 99 & 70.71 \\
& Animal feed & 27 & 19.29 \\
& Bury & 8 & 5.71 \\
& Compost & 4 & 2.86 \\
\hline Paper/ cardboard & Municipal council truck & 106 & 75.71 \\
& Burn & 24 & 17.14 \\
& Reuse & 5 & 3.57 \\
& Compost & 2 & 1.43 \\
& Bury & 1 & 0.71 \\
& Recycle & 1 & 0.71 \\
\hline Solid (plastic, metals & Municipal council truck & 125 & 89.29 \\
glass, etc.) & Bury & 9 & 6.43 \\
& In yard & 6 & 4.29 \\
\hline
\end{tabular}

Table 2. Reason for dissatisfaction with the Urban Council collection service.

\begin{tabular}{ll}
\hline Reasons & Percentage \\
\hline Frequency of service (The interval between the collections is too long) & 41.4 \\
The collection workers are impolite & 26.4 \\
The service is not reliable & 15.0 \\
\hline
\end{tabular}

About $67 \%$ of the households were concerned about the illegal dumping in their area. $82.14 \%$ of the households were concerned about litter in their area. $70.71 \%$ of the household were concerned about the presence of rats in their area and $87.14 \%$ of the household were concerned about flooding due to waste blocking drains and gullies. Majority of the households (71.43\%) were willing to collect more information about how and what type of waste can be composted, reused and recycled in order to reduce the amount of waste that they need to get rid of. Table 4 presents the three initial fee levels used in this study, which were based on municipal council reporting at the time of the survey. $30 \%$ of all respondents accepted the initial fee (LKR 5). 7\% accepted the second bid (LKR 4). $28 \%$ accepted the third bid (LKR 3). Collectively, 61 percent of the sample accepted one of the three bids and declared a positive WTP.

\section{Regression results}

As indicated in the methods, we fitted regression models on WTP. The first model was to explain the WTP for a better collection service (Table 5).
Model results revealed a R-squared value of 0.68 which implied that about $68 \%$ of the variation in the household willingness to pay was explained by the factors such as age, gender, marital status, education, size of household, average income, household concern about environment and service provide by KMC, quantity of waste and cost of collecting $1 \mathrm{~kg}$ of waste.

The results showed that respondents' age, marital status, size of household, quantity of waste and household concern about the service provided by KMC do not significantly influence the willingness to pay for improved waste collection service. However, household willingness to pay was significantly affected by gender, education, average income, household concern about environment and cost of collecting $1 \mathrm{~kg}$ of waste. Gender and education were statistically significant at $p<0.05$, average income and cost of collecting $1 \mathrm{~kg}$ of waste were statistically significant at $p<0.1$ and household concern about environment was statistically significant at $\mathrm{p}<0.01$. 
Table 3. Household concerns about solid waste management.

\begin{tabular}{lcc} 
Views/Concerns on SWM & $\begin{array}{c}\text { Concerned } \\
\mathbf{\%}\end{array}$ & $\begin{array}{c}\text { Not concerned } \\
\mathbf{\%}\end{array}$ \\
\hline $\begin{array}{l}\text { Are you concerned about health risks related to burning } \\
\text { waste? }\end{array}$ & 82.86 & 17.14 \\
$\begin{array}{l}\text { Are you concerned about illegal dumps polluting rivers, } \\
\text { streams, and wells? }\end{array}$ & 82.14 & 17.86 \\
$\begin{array}{l}\text { Are you concerned about diseases that are related to } \\
\text { improper storage and disposal methods, like Dengue? }\end{array}$ & 83.57 & 16.43 \\
$\begin{array}{l}\text { Are you concerned about flooding due to waste blocking } \\
\text { drains and gullies? }\end{array}$ & 87.14 & 12.86 \\
$\begin{array}{l}\text { Are you concerned about the service provided by the } \\
\text { municipal council in this area? }\end{array}$ & 97.14 & 2.86 \\
$\begin{array}{l}\text { Are you concerned about litter in this area? } \\
\text { Are you concerned about illegal dumping in this area? }\end{array}$ & 82.14 & 17.86 \\
Are you concerned about the presence of rats in this area? & 67.86 & 32.14 \\
\hline
\end{tabular}

Table 4. Willingness to pay responses for initial fee

\begin{tabular}{lccc}
\hline \multirow{2}{*}{ Response } & \multicolumn{3}{c}{ Fee } \\
\cline { 2 - 4 } & Rs 5.00 & Rs 4.00 & Rs 3.00 \\
\hline No. of "yes" responses & 42 & 9 & 34 \\
No. of "no" responses & 98 & 89 & 55 \\
\hline
\end{tabular}

Table 5. Factors affecting on household willingness to pay for improved waste collection.

\begin{tabular}{lcc}
\hline Independent Variables & Coefficient & Standard Error \\
\hline Gender & $0.469^{* *}$ & 0.229 \\
Marital states & -0.405 & 0.436 \\
Age & -0.007 & 0.012 \\
Household size & 0.014 & 0.114 \\
Education & $0.090^{* *}$ & 0.044 \\
Average income & $0.298^{*}$ & 0.169 \\
Quantity of household waste & -0.103 & 0.162 \\
Environmental sensitivity & $3.082^{* * *}$ & 0.265 \\
Level of service provided by KMC & -0.365 & 0.657 \\
Cost of collecting 1kg of waste & $0.064^{*}$ & 0.033 \\
Constant & -1.161 & 1.094 \\
\hline
\end{tabular}

(No $\left.=140, \mathrm{R}^{2}=0.6881, \mathrm{~F}=28.46^{* * *}\right)$

${ }^{*}$ Significance at $10 \%$ level; ${ }^{* *}$ Significance at $5 \%$ level; ${ }^{* *}$ Significance at $1 \%$ level

Education level is positively related to WTP for improved waste collection service. The results showed that an increase in education by one year increases the willingness to pay by 9 cents. The positive relationship between education and WTP for better waste management services is also supported by other studies (Aggrey and Douglason,
2010; Sumukwo, Kiptui and Cheserek, 2012; Bhattarai, 2015). Gender (female) is positively related to WTP for improved waste collection service. Adepoju and Salimonu (2006) also found that female gender significantly influenced to the household's willingness to pay amount for improved solid waste management. 
The average income of the household positively influences household's WTP. The result showed that an increase in household income by one LKR increases the willingness to pay by 0.29 LKR. This relationship is also supported by similar studies (Padi, Addor and Nunfam, 2015; Bhattarai, 2015; Anjum, 2013; Aggrey, Douglason, 2010). The declared environmental sensitivity has a positive relationship to WTP for improved waste collection service. This result shows that households are more likely to pay for an improved waste collection service if they are aware of the adverse impacts of waste on the environment. Other studies (Padi, Addor and Nunfam, 2015; Hagos, Mekonnen and Gebreegziabher, 2012) share similar connections between awareness and WTP.

The second estimation consisted of two models. One explained the WTP for organic waste disposal and the other explained the plastic and paper disposal (Table 6). We observe that education, environment sensitivity of the residents and income as strong predictors.

Our results are broadly supported by other studies looking into SWM. For instance, studies have also shown that age influences the WTP for solid waste disposal services. Ekere et al. (2010) and Afroz et al., (2009) pointed out that, holding all other factors constant, older people are willing to pay more than younger people. This means that older citizens make more mature decisions related to assessing health and environmental issues, possibly due to their age, leading them to express a high WTP value. Alternatively, Aggrey and Douglason (2010) indicate that age negatively affects willingness to pay. They observe that older people might consider waste collection as the government's responsibility and could be less willing to pay for it, while the younger generation might be more familiar with cost sharing and could be willing to pay. Household size is another factor that influences WTP for waste management. Addai and Danso-Abeam (2014) pointed out that the more the number of people in the household, the more the household will appreciate a clean environment. Tamura (2005), in analyzing the individual attributes of the demand for solid waste collection in Accra, find that the more income people have, the more willing they are to pay for solid waste collection. This implies that there is a positive correlation between income and people's willingness to pay for solid waste disposal services.

The quantity of waste generated by a household also influences WTP for waste disposal services. Aggrey and Douglason (2010) points out that the higher the generation of waste, the more the household faces the challenges of waste disposal and the greater the willingness to pay.

Table 6: Explaining the willingness to pay to dispose $1 \mathrm{~kg}$ of waste types (organic vs inorganic)

\begin{tabular}{lcc}
\hline Independent Variables & Organic/kitchen waste. & Paper and plastic \\
\hline Gender & 0.342 & 0.451 \\
Marital states & -0.817 & -0.281 \\
Age & 0.009 & 0.015 \\
Household size & $0.667^{* * *}$ & -0.104 \\
Education & $0.191^{* *}$ & $0.177^{* * *}$ \\
Average income & $0.532^{* *}$ & $0.674^{* * *}$ \\
Quantity of household waste & -0.236 & 0.155 \\
Environmental sensitivity & $3.396^{* * *}$ & $2.979^{* * *}$ \\
Cleanliness & -0.095 & 0.071 \\
Health priorities & -0.097 & -0.171 \\
Cost of collecting 1kg of waste & 0.073 & 0.038 \\
Waste storage methods & -0.082 & -0.034 \\
Waste separation at home & 0.080 & 0.258 \\
Constant & $-5.369^{* * *}$ & $-4.206^{* * *}$ \\
\hline Observations & 140 & 140 \\
R & 0.5595 & 0.6150 \\
F & $12.31^{* * *}$ & $15.48^{* * *}$ \\
\hline
\end{tabular}

*Significance at $10 \%$ level; ${ }^{* *}$ Significance at $5 \%$ level; ${ }^{* * *}$ Significance at $1 \%$ level 
An important observation that arises from the model results is the lack of explanatory power of factors such health priorities, cleanliness, and waste separation experience in explaining the willingness to pay. In addition to education and income, the only other robust predictor of positive WTP is the environmental values of the respondent. Collectively, the findings reveal that the households' perception of the waste problem is quite primitive and not sensitive to location specific factors. This is perhaps due to the absence of localized approaches to waste management in many municipalities, which still rely on regional collection and disposal outside the urban perimeters making the waste management challenge less visible to actual waste generators.

\section{REFERENCES}

Addai, N. K., Danso-Abbeam, G. (2014). Determinants of willingness to pay for improved solid waste management in Dunkwaon-Offin, Ghana. Unpublished report.

Afroz, R., Hanaki, K., Hasegawa-Kurisu, K. (2009). Willingness to pay for waste management improvement in Daka city, Bangladesh. Journal of Environment Management. 90 (3), 492-502.

Aggrey, N., Douglason, G.O. (2010). Determinants of willingness to pay for solid waste management in Kampala City. Current Research Journal of Economic Theory, 2(3), 119-122.

Anjum, R. (2013) Willingness to Pay for Solid Waste Management Services: A Case Study of Islamabad; Pakistan Institute of Development Economics: Islamabad, Pakistan.

Asian Productivity Organization (2007). Solid Waste Management Issues Challengers in Asia, Sri Lanka. ISBN: 92-833-7058-9, pp. 246-273.

Bhattarai, K. (2015). Households' willingness to pay for improved solid waste management in Banepa municipality, Nepal. Environment and Natural Resource Journal. 13(1), 14-25.

Ekere, W., Mugisha, J. and Drake, L. (2010). Willingness to pay for sound waste management in urban and peri-urban areas of the Lake Victoria crescent region Uganda. Second RUFORUM Biennial Meeting 20-24 September 2010, Entebbe, Uganda.
Municipal solid waste collection in Sri Lanka primarily lacks substantive public participation. Commercial clients and households, who are the primary producers of solid waste and the victims of negative implications of uncollected solid waste, need to be more directly participating in municipal discussions on improving SWM and structuring effective public-private partnerships to deliver such services. In doing so, the municipality authorities will better understand households' demands and motivation. Such an understanding can be greatly benefited by establishing how much households are willing to pay for efficient and costeffective delivery of solid waste services to residential areas. The findings from this study will help the local government and concerned stakeholders to understand the relevant characteristics of households and come up with a suitable fee for the waste collection service.

Environmental Foundation (2007). Climbing Out of the Garbage Dump: Managing Colombo solid waste problem. EFL Policy Paper, January 2007.

Ghosh, S, Mondal S (2011). Morbidity, Health expenditure and willingness to pay for health insurance amongst the urban poor a case study. Journal of Health Management, 13(4), 419-437.

Gunawardana, E.G.W., Basnayake, B.F.A., Shimada, S., Iwata, T. (2009). Influence of biological pretreatment of municipal solid waste on landfill behaviour in Sri Lanka. Waste Management Research.27(5), 456-462.

Hagos, D., Mekonnen, A., Gebreegziabher, Z. (2012) Households' Willingness to Pay for Improved Urban Waste Management in Mekelle City, Ethiopia. Unpublished report.

Lang, H.C. (2010). Willingness to pay for lung cancer treatment. Value in Health. 13(6), 743749.

Mahees, M.T.M., Sivayoganathan, C. and Basnayaka, B.F.A. (2011). Consumption, solid waste generation and water pollution in Pingaoya catchment area. Tropical Agriculture Research, 22(2), 239-250.

Muneera, M., Kaleel, B. M. I. M.(2016).Emerging challenges of urbanization: a case study of Kalmunai municipal area in Ampara district. World Scientific News 59, 35-51.

Ojok, J., Koech. M.K., Tole M., OkotOkumu, J. (2012). Households' Willingness to Pay for Improved 
Municipal Solid Waste Management Services in Kampala, Uganda. Science Journal of Environmental Engineering Research ISSN: 2276-7495.

Padi, A.; Addor, J.A.; Nunfam, V.F. (2015) An econometric model of factors influencing households' willingness to pay for improved solid waste management service within the Sekondi-Takoradi metropolis in the western region of Ghana. Journal of Economic Sustainability and Development, 6(1), 15-29.

Singh, R.P., Singh.P.,Araujo, A.S.F., Ibrahim, M.H., Sulaiman, O. (2011). Management of urban solid waste: Vermicomposting a sustainable option. Resources, Conservation and Recycling. 55 (3), 719-729.

Sumukwo, J.; Kiptui, M.; Cheserek, G.J. (2012) Economic valuation of improved solid waste management in Eldoret municipality. Journal of Emerging Trends in Economics and Managment Science. 3 (4), 962-970.

Tamura K. (2005). The demand for solid waste collection in Accra (Ghana). Unpublished MA Dissertation submitted to the Faculty of the Centre for International Studies of Ohio University.

Van Zon, L., Siriwardena, N. (2000). Garbage in Sri Lanka: An Overview of Solid Waste Management in the Ja-Ela Area. Colombo: Integrated Resources Management Program in Wetlands.

Wel, A., Post, V. (2007). Solid waste management in Sri Lanka: policy and strategy. WASTE project report. Nieuwehaven 201, 2801 CW Gouda. 